\title{
Determinate the Number of Growth Rings Using Resistograph with Tree-Ring Chronology to Investigate Ages of Big Old Trees ${ }^{1}$
}

\author{
Jung-Ae $\mathrm{OH}^{2} \cdot$ Jeong-Wook $\mathrm{SEO}^{3} \cdot$ Byung-Ro KIM ${ }^{3, \dagger}$
}

\begin{abstract}
To verify the possibility of using resistograph to estimate the age of big old living trees, we selected three Zelkova serrata and seven Pinus densiflora in Goesan. The mean diameters at breast height of Z. serrata and P. densiflora were $102(92-116) \mathrm{cm}$ and $80(65-110) \mathrm{cm}$, respectively. The heights measured from the ground using a resistograph ranged at $1.2-4.3 \mathrm{~m}$ and $0.6-1.1 \mathrm{~m}$ for $Z$. serrata and $P$. Densiflora, respectively. The most appropriate needle speed to determine tree-ring boundaries for measuring ring width was $1500 \mathrm{r} / \mathrm{min}$ for both tree species. Alternatively, the suitable feed speeds for $Z$. serrata and $P$. densiflora were $50 \mathrm{~cm} / \mathrm{min}$ and $150 \mathrm{~cm} / \mathrm{min}$, respectively. From the measured data, the mean numbers of tree rings of $Z$. serrata and $P$. densiflora were 57 (43-68) and 104 (93-124), respectively, and the mean tree-ring widths were $4.27 \mathrm{~mm}(3.18-5.09 \mathrm{~mm})$ and $2.93 \mathrm{~mm}(2.32-3.34 \mathrm{~mm})$, respectively. A comparison between the time series of tree-ring widths by resistograph and that from the local master chronologies tallied for the heartwood part. Finally, this study showed that resistograph can be used to estimate tree ages when a local master chronology is available.
\end{abstract}

Keywords: tree age, Resistograph, electric resistance values, feed and needle speed, tree-ring, conifer trees, deciduous tree

\section{INTRODUCTION}

Since ancient times till now, the people of many villages in South Korea offer sacrifices to big old trees, usually located at village entrances for the peace of their villages (Heo et al., 2011). The places, where the big old trees are, have also been used as public spaces where all the villagers gather to perform various local events (Ahn \& Choi, 2001; Jeong \& Yoon, 2014;
Jung \& Kim, 2017). Therefore, big old trees have historical and cultural values. Based on these cultural values of big old trees, national and local governments established the Forest Protection Act (Article 13, designation and management of the law-protected trees) or an Ordinance to designate and manage the trees as a natural monument or law-protected trees.

Tree age is one of the important parameters to evaluate the historical and cultural values of big old

\footnotetext{
${ }^{1}$ Date Received June 17, 2019, Date Accepted October 24, 2019

${ }^{2}$ Wood Products Quality \& Safety Management Division, Korea Forestry Promotion Institute, Seoul, 07570, Republic of Korea

${ }^{3}$ Department of Wood and Paper Science, Chungbuk National University, Cheongju 28644, Republic of Korea

$\dagger$ Corresponding author: Byung-Ro KIM (e-mail: brkim@cbnu.ac.kr, ORCID: 0000-0001-5800-2058)
} 
trees. For this reason, we tried to estimate the age as accurately as possible. There are three representative methods to investigate a tree's age, viz. tree rings, nodes, and diameter (Son et al., 2007). The most accurate method of these three is to count the number of tree rings(Jeong et al., 2017; Seo et al., 2017a, b). Especially, the number of tree rings at the boundary between the root and stem represents the tree age (Part et al., 1987). However, it is almost impossible to investigate tree rings at the boundary without cutting the tree. Therefore, the tree age is normally investigated using increment cores extracted at breast height of the stem, and in order to estimate more precisely, the estimated year is added to the height growth from the ground up to the breast level (Wong \& Lertzman, 2001).

Now, during sampling using an increment borer, wounding the stem cannot be avoided. Although this wounding does not impart a great effect on the tree growth and/or the life of the tree, we are reluctant to use an increment borer for sampling. Resistograph is an equipment designed to measure the degree of wood decay, cavities, and crack (Frank, 1994, 2013; Gruber, 2000). The operation of a resistograph is based on electrical resistance It comprises an electronically controlled drill resistance which has a strong linear relationship with wood density (Frank, 2012). Conifer and ring porous trees in temperate zone show the lowest and highest densities in the early- and latewood within the tree rings, respectively (Schweingruber, 1988). Using the pattern of density variations measured by resistograph, we can investigate tree ages (Bilgin et al., 2012; Lukaszkiewicz et al., 2005). The greatest advantage of a resistograph in counting and/or measuring tree rings is that it makes smaller wounds (Ø $2 \mathrm{~mm}$ ) than the ones by an increment borer (Ø more than $5 \mathrm{~mm}$ ). In previous study, it was verified that resistograph can most perfectly measure tree-ring widths larger than $1 \mathrm{~mm}$ (Oh et al., 2019).

Decay within trees is one of difficulties in investigat- ing tree ages. Most big old trees are partially decayed and the decayed locations are variously distributed within the stems. Due to such conditions, it is difficult to obtain continuous tree rings from the bark to the pith, and therefore, it is a challenge to measure the innermost tree ring, which is the most important reference in determining the tree age. In dendrochronology, dating is done by comparing an undated tree-ring time series with a dated long tree-ring time series (master chronology), which is called 'cross-dating' (Schweingruber, 1988). This method can be used to identify the logging year of the timber, to date wooden artifacts excavated at the site(Lee et al., 2018), and to track the origin of the timber(Eckstein and Wrobel, 2007). If we have longer than around 50-year time series with the inner most tree ring, the inner most tree ring can be dated by the cross-dating method. Oh et al. (2017) established the master chronology of Pinus densiflora and Zelkova serrata for the provinces of Goesan in Chungbuk, Gurae in Jeonna, and Uljin in Gyeongbuk in a previous report.

The current study explored the possibility of applying resistograph to establish the tree-ring time series of big old living trees (Pinus densiflora and Zelkova serrata) in Goesan based on the results of Oh et al. (2019), and then, to date the tree rings by comparing the time series with the master chronology established by $\mathrm{Oh}$ et al. (2017). We believe that the results of our study could be used as a practical reference in estimating the tree age using resistograph.

\section{MATERIALS and METHODS}

\subsection{Materials}

For the present study, ten big old trees from Goesangun in Chungbuk were selected of which 3 were Zelkova serrata and 7 were Pinus densiflora. These tree species occupy 52\% (7,302 trees) and 13\% (1,753 trees) of all the protected trees, respectively (Korea Forest 
Table 1. Description of the study sites and analyzed trees

\begin{tabular}{|c|c|c|c|c|}
\hline Tree & Site & ID & $\begin{array}{l}\text { Diameter } \\
(\mathrm{cm})\end{array}$ & $\begin{array}{l}\text { Measurement height } \\
\text { from the ground }(\mathrm{m})\end{array}$ \\
\hline \multirow{3}{*}{ Zelkova serrata } & \multirow{3}{*}{ Cheongcheon-ri } & CBGSZS12 & 92 & 4.3 \\
\hline & & CBGSZS13 & 116 & 1.2 \\
\hline & & CBGSZS14 & 98 & 1.4 \\
\hline \multirow{7}{*}{ Pinus densiflora } & \multirow{7}{*}{ Jujin-ri } & CBGSPD04 & 66 & 0.6 \\
\hline & & CBGSPD05 & 70 & 1.0 \\
\hline & & CBGSPD06 & 65 & 0.7 \\
\hline & & CBGSPD07 & 102 & 1.0 \\
\hline & & CBGSPD08 & 110 & 1.0 \\
\hline & & CBGSPD09 & 65 & 1.0 \\
\hline & & CBGSPD10 & 79 & 1.1 \\
\hline
\end{tabular}

Service, 2018). The mean diameters at breast height (DBH) of Zelkova serrata and Pinus densiflora are 102 (92-116) $\mathrm{cm}$ and $80(65-110) \mathrm{cm}$, respectively (Table 1). The measurement heights from the ground using resistograph were between 1.2 and $4.3 \mathrm{~m}$ for Zelkova serrata, and between 0.6 and $1.1 \mathrm{~m}$ for Pinus densiflora.

\subsection{Methods}

\subsubsection{Ring width measurement by resistograph}

Resistograph (IML-RESI PD400, Germany) was used to measure the tree-ring widths. By IML Australia (C) (2013), tree-ring boundaries can be clearly distinguished at electrical resistance range of $40-60 \%$ of the resistograph. In a previous study (Oh et al., 2019), it was suggested that the needle and feed speeds of resistograph should be decided by performing a pre-test field work. The measurement depth of the resistograph was $40 \mathrm{~cm}$, which was actually the length of the needle (Fig. 1).

With respect to the current amplitudes of the resistograph from the bark to the pith in the stem of Zelkova serrata, the lowest part of the wave was considered as the tree-ring boundaries (Fig. 2), since the porous rings have the lowest wood density at the
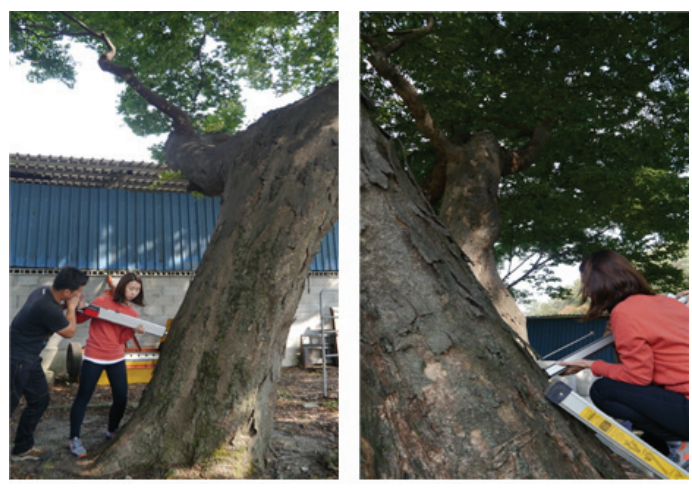

Fig. 1. Measurement of electrical resistance from the bark to the pith in a stem using resistograph.

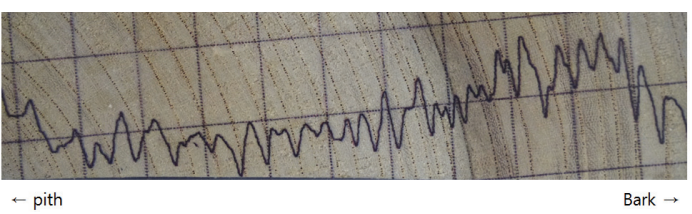

Fig. 2. Resistograph profile of Zelkova serrata and its tree rings (feed speed $75 \mathrm{~cm} / \mathrm{min}$ ).

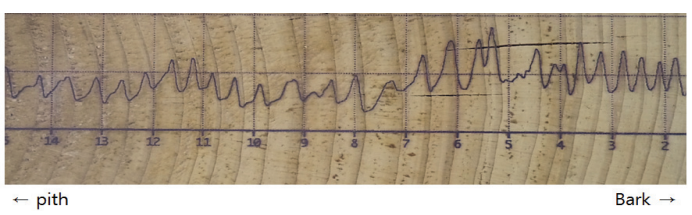

Fig. 3. Resistograph profile of Pinus densiflora and its tree rings (feed speed $150 \mathrm{~cm} / \mathrm{min}$ ). 

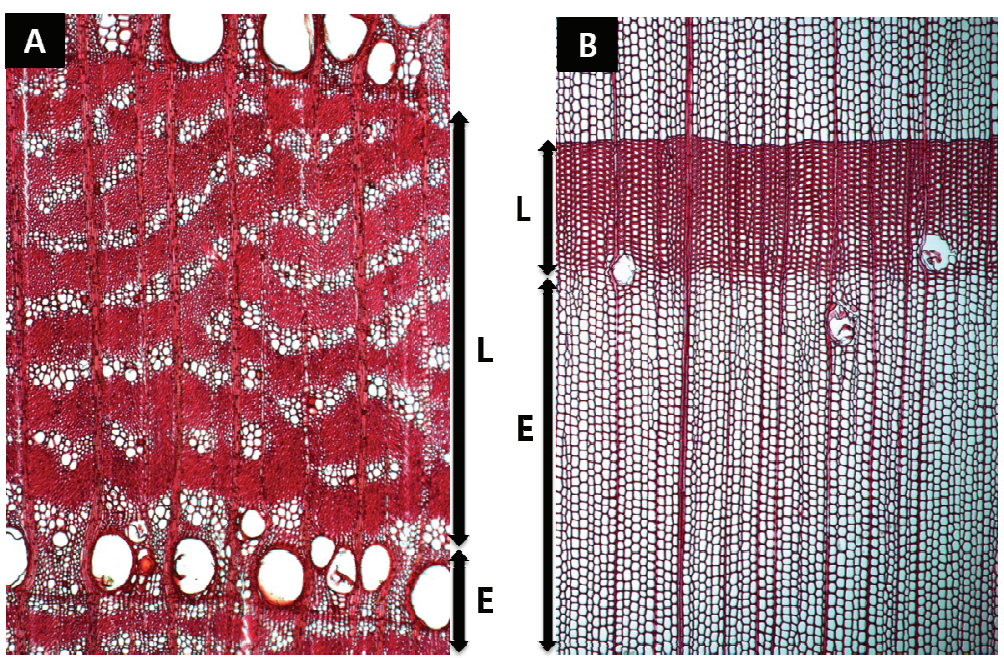

Fig. 4. Cross-sections of (A) Zelkova serrata and (B) Pinus densiflora (L: latewood, E: earlywood).

beginning of the tree rings where large pores were formed (Fig. 4A). Although the ring boundaries will somehow shift to the locations of the large pores in the next year, no calibration is necessary because such shifts occurred uniformly in all the tree rings. On the other hand, the tree-ring boundaries of Pinus densiflora were determined at the end of tree rings having the highest wood density and where latewood cells with small diameters and thick cell walls in the radial direction are present (Fig. 3). In this case, the boundaries were slightly shifted to the latewood in the current year due to same locations of the cells with the highest density within the tree rings (Fig. 4B) (Schweingruber, 1988). Similar to Zelkova serrata, the shifting effects did not require any calibration because such shifting were present in all the tree rings.

\subsubsection{Comparison of the ring-width time series by resistograph with the local master chronologies}

The ring-width time series established by electrical resistance measurement of resistography (PD-tool pro) were compared with the local master chronologies of Zelkova serrata and Pinus densiflora, established by Oh et al. (2017), to develop a time series using tree rings near the pith.

\section{RESULTS and DISCUSSION}

\subsection{Feed and needle speeds}

The most proper needle speed to determine tree-ring boundaries for the ring-width measurement was verified as $1500 \mathrm{r} / \mathrm{min}$ for both the tree species (Fig. 5). Whereas, the suitable feed speeds for Zelkova serrata and Pinus densiflora were $50 \mathrm{~cm} / \mathrm{min}$ and $150 \mathrm{~cm} / \mathrm{min}$, respectively.

In the previous study (Oh et al., 2017), it was suggested that the most suitable needle speed to determine tree-ring boundaries in the measurement data was $1500 \mathrm{r} / \mathrm{min}$ for all the experimental tree species (Pinus koraiensis, Larix kaempferi, Pseudotsuga menziesii, Abies holophylla and Zelkova serrata), which was done using disks. In the current study, although 


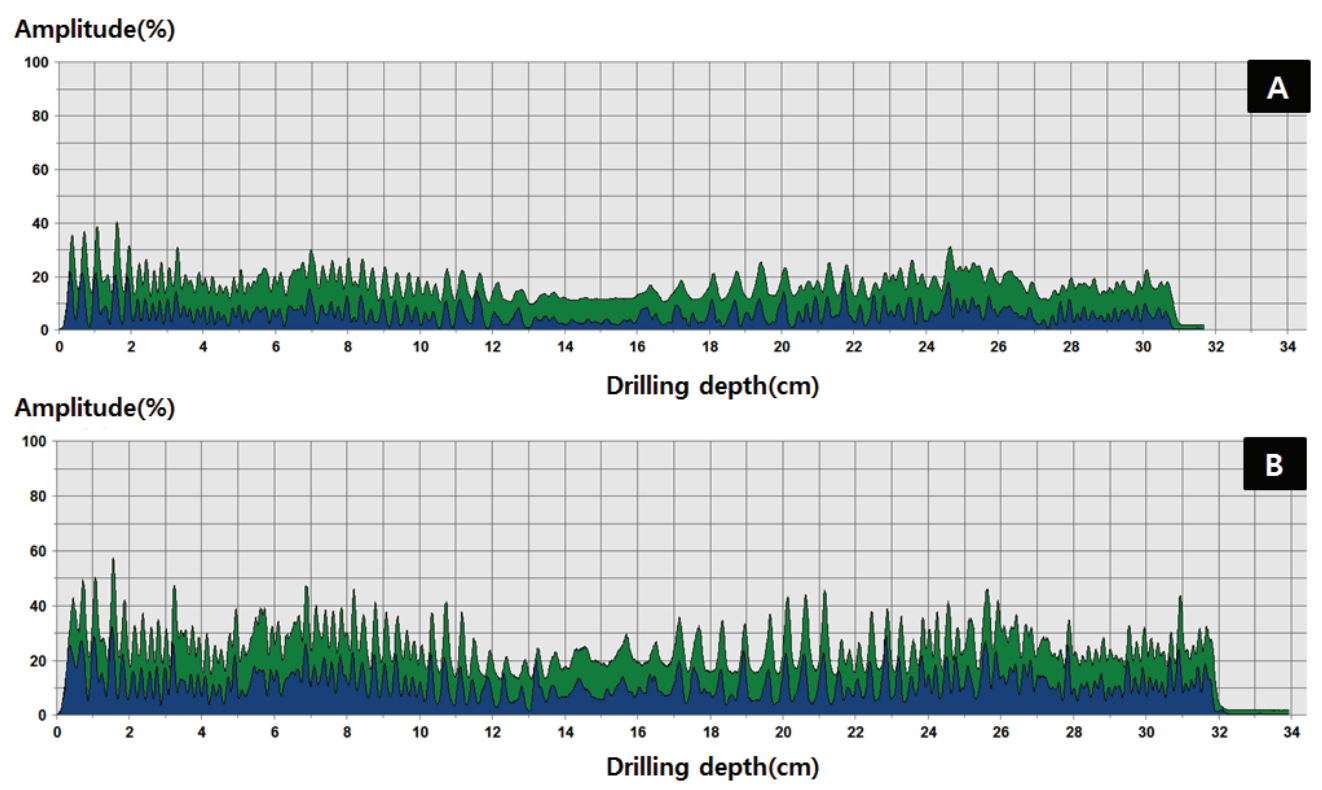

Fig. 5. Graphs of needle speeds of $2500 \mathrm{r} / \mathrm{min}$ (A) and $1500 \mathrm{r} / \mathrm{min}$ (B) for Pinus densiflora.

resistograph was applied, the most suitable needle speed was also verified to be $1500 \mathrm{r} / \mathrm{min}$. Based on these results, the needle speed of $1500 \mathrm{r} / \mathrm{min}$ might be the most proper option for measurement of tree-ring widths in general.

The feed speeds should be set differently depending on the density difference of the species(Frank, 1994). The feed speeds to determine tree-ring boundaries suggested by $\mathrm{Oh}$ et al. (2017) were different depending upon the tree species. The most suitable feed speed for Larix kaempferi and Pseudotsuga menziesii was 100 $\mathrm{cm} / \mathrm{min}$, for Pinus koraiensis $175 \mathrm{~cm} / \mathrm{min}$, for Abies holophylla $150 \mathrm{~cm} / \mathrm{min}$, and for Zelkova serrata $75 \mathrm{~cm} / \mathrm{min}$. In our study, however, the most suitable feed speed for Zelkova serrata was found to be $50 \mathrm{~cm} / \mathrm{min}$, different from the past report (Oh et al., 2017). Although there is no reference for Pinus densiflora, the proper feed speed for this tree was same as that of Abies holophylla, i.e. $150 \mathrm{~cm} / \mathrm{min}$. The differences of feed speeds between living trees and wood is due to different moisture content in the stems and disks (Bilgin et al., 2012).

\subsection{Tree-ring time series established by resistograph}

As illustrated in Fig. 6 and 7, three tree-ring time series of 3 big old Zelkova serrata and 7 big old Pinus densiflra were established. The mean number of tree rings of Zelkova serrata and Pinus densiflora were 57 (43-68) and 104 (93-124) and the mean tree-ring widths were $4.27 \mathrm{~mm}(3.18-5.09 \mathrm{~mm})$ and $2.93 \mathrm{~mm}(2.32-3.34$ $\mathrm{mm}$ ), respectively (Table $2 \& 3$ ).

According to Oh et al. (2019), resistograph fails to measure tree-ring boundaries which are narrower than $1 \mathrm{~mm}$. Therefore, the results showed differences between the number of tree rings observed in disks and those counted from the measurement data. Similarly, in the current study, the tree rings which are narrower than $1 \mathrm{~mm}$ will also not be well detected if the resistograph data are used. Therefore, the number of tree rings would be lower than the real existing tree rings. Especially, such errors would be more predominant in the sapwood due to aging effect (Schweingruber, 1988; Park 1993). 
Determinate the Number of Growth Rings Using Resistograph with Tree-Ring Chronology to Investigate Ages of Big Old Trees

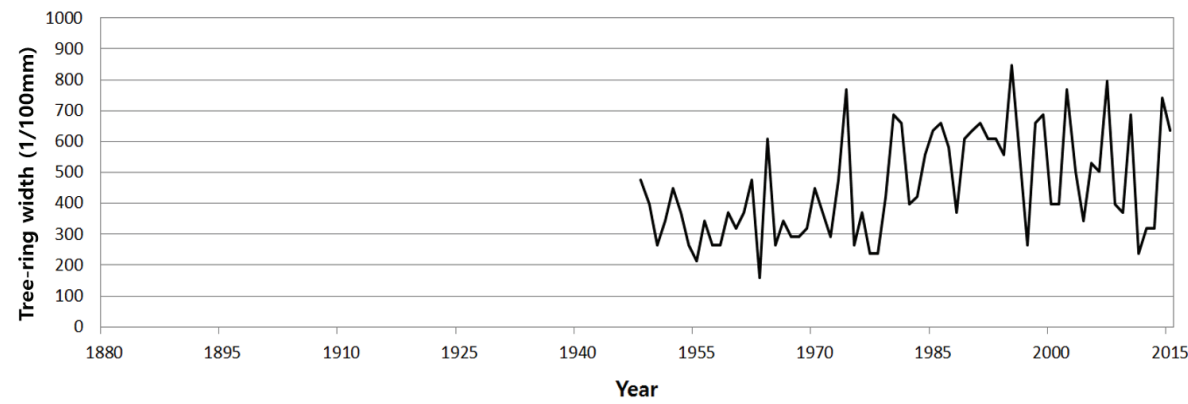

Fig. 6. Annual tree-ring time series of Zelkova serrata (CBGSZS12) by resistograph.

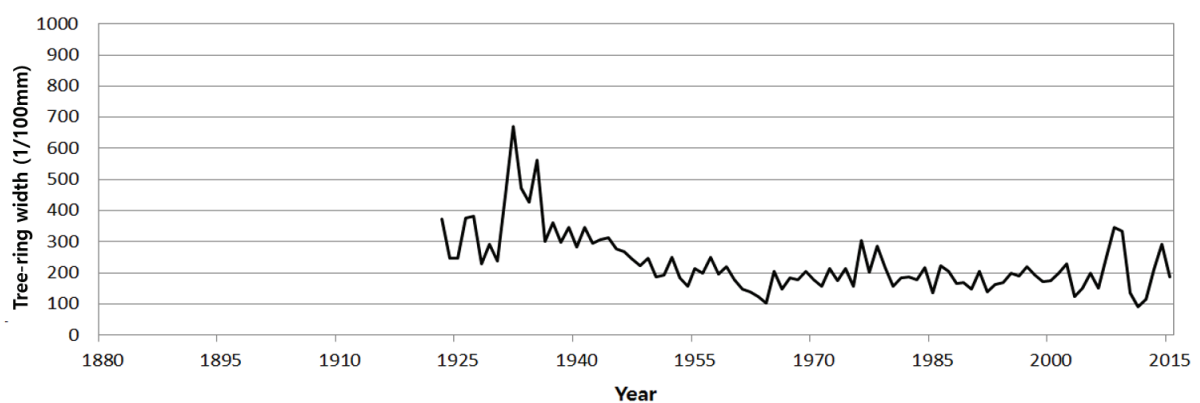

Fig. 7. Annual tree-ring time series of Pinus densiflora (CBGSPD04) by resistograph.

Table 2. Information on the tree-ring widths of Zelkova serrata by resistograph

\begin{tabular}{cccccc}
\hline \multirow{2}{*}{ ID } & \multirow{2}{*}{$\begin{array}{c}\text { No. of measured } \\
\text { direction }\end{array}$} & Number of tree rings & \multicolumn{3}{c}{ Tree-ring width (mm) } \\
\cline { 5 - 7 } & 2 & 68 & Minimum & Mean & Maximum \\
\hline \hline CBGSZS12 & 1 & 43 & 1.59 & 4.55 & 8.47 \\
CBGSZS13 & 2 & 60 & 2,12 & 3.18 & 6.35 \\
CBGSZS14 & 2 & & 5.09 & 10.58 \\
\hline
\end{tabular}

Table 3. Information on the tree-ring widths of Pinus densiflora by resistograph

\begin{tabular}{cccccc}
\hline \multirow{2}{*}{ ID } & $\begin{array}{c}\text { No. of measured } \\
\text { direction }\end{array}$ & Number of tree rings & \multicolumn{3}{c}{ Tree-ring width (mm) } \\
\cline { 5 - 6 } CBGSPD04 & 2 & 93 & Minimum & Mean & Maximum \\
\hline \hline CBGSPD05 & 2 & 109 & 1.26 & 2.32 & 6.72 \\
CBGSPD06 & 2 & 94 & 1.11 & 2.78 & 9.41 \\
CBGSPD07 & 2 & 103 & 1.35 & 3.34 & 5.72 \\
CBGSPD08 & 2 & 124 & 1.14 & 2.96 & 7.06 \\
CBGSPD09 & 2 & 103 & 1.26 & 3.22 & 7.74 \\
CBGSPD10 & 2 & 108 & 1.05 & 3.04 & 9.23 \\
\hline
\end{tabular}



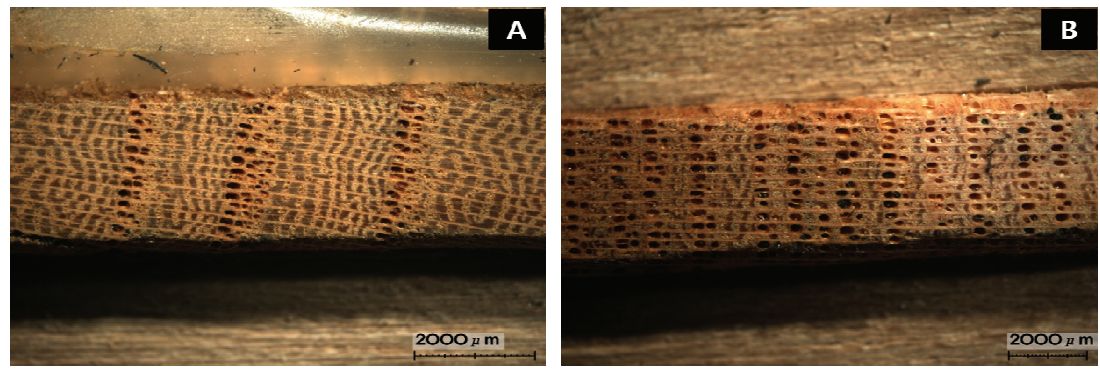

Fig. 8. Distinct tree-ring boundaries (A: heartwood) and indistinct one (B: sapwood) for Zelkova serrata $(\times 10)$.
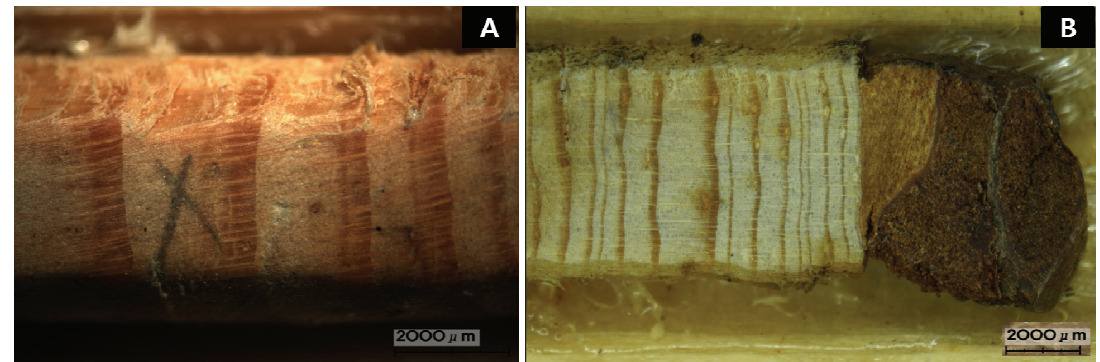

Fig. 9. Distinct tree-ring boundaries (A: heartwood) and indistinct one (B: sapwood) for Pinus densiflora $(\times 10)$.
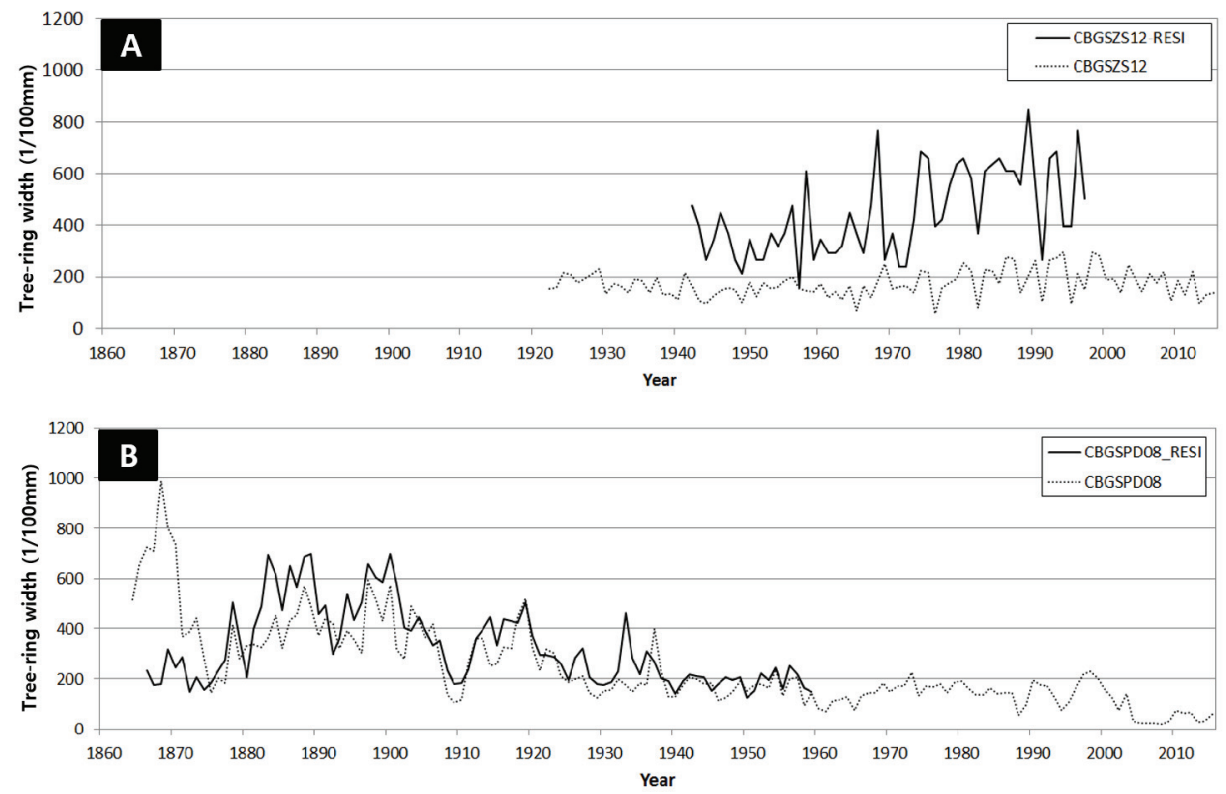

Fig. 10. Cross-dating after removing sapwood (A: CBGSZS12, B: CBGSPD08). 


\subsection{Comparison of tree-ring time series by resistograph with the local master chronologies}

The tree rings in the sapwood are usually narrower than ones in the heartwood (Fig. $8 \& 9$ ). Therefore, the cross-dating technique was mostly applied to the tree rings in the heartwood for dating. By employing this strategy for cross-dating, the calendar year of the innermost tree rings could be successfully dated (Fig. 10). Therefore, the present study verified that the tree-ring time series by resistograph represent the real ring-width time series in the heartwood. To use resistograph to estimate the tree ages in other provinces, master chronologies, which are responsible for various tree species and provinces, need to be established.

\section{CONCLUSION}

To conclude, tree-ring time series for big old trees was established and tree-ring was dated. The most suitable needle speed to establish tree-ring time series for living big old Zekova serrata and Pinus densiflora using resistograph was $1500 \mathrm{r} / \mathrm{min}$, whereas the most suitable feed speeds were $50 \mathrm{~cm} / \mathrm{min}$ for the former and $150 \mathrm{~cm} / \mathrm{min}$ for the latter. Although tree rings narrower than $1 \mathrm{~mm}$ and/or in the sapwood could not be well detected from the electrical measurement data of resistograph, it was verified that the tree rings in heartwood can be distinguished using the measured data. Therefore, the time series by resistograph can be dated with the available master chronology using the measurement data of tree-ring widths. Based on these results, we conclude that resistograph can be applied to estimate the age of trees located where a local master chronology is available.

\section{REFERENCES}

Ahn, Y.H., Choi, K.Y. 2001. A study on the distribution and present situation of the big and old trees in
Pyongtaek Kyonggi-do province, Korea. Journal of Food Resources Institute 13(1): 31-45.

Bilgin, G., Adnan, G., Gokhan, K. 2012. Is Resistograph an Appropriate Tool for the Annual Ring Measurement of Pinus brutia. NDE for safety / Defektoskopie 2012.

Eckstein, D., Wrobel, S., 2007. Dendrochronological Proof of Origin of Historic Timber: Retrospective and Perspectives. Tree Rings in Archaeology, Climatology and Ecology-Proceedings of the Dendrosymposium 2006, 20-24 April 2006, Tervuren, Belgium 5: 8-20.

Frank, R. 1994. Resistographic Visualization of Treering Density Variations. International Conference on Tree Rings, Environment, and Humanity.

Frank, R. 2012. Basics of micro-resistance drilling for timber inspection. Holztechnologie 53(3): 24-29.

Frank, R. 2013. Detecting Fungal Decay in Palm Stems by Resistance Drilling. Florida arborist spring 2013.

Gruber, F. 2000. Vergleichende Messergebnisse zur Identifizierung von Schadstellen im Fichtenholz (Picea abies L. Karst.) mit den Bohrmessgeäten Teredo, Resistograph 1410 und Impulshammer Schallmesssystem. Allgemeine Forest und Jagdzeitung 172.

Heo, B.S., Kim, H.J., Lee, W.H., Kang, H.J. 2011. Growth conditions and maintenance of natural monument old big trees in Gangwondo. MUNHWAJAE Korean Journal of Cultural Heritage Studies 44(1): 182-195.

Jeong, W.J., Yoon, S.J. 2014. Utilization of the old big tree and its surrounding space pertaining to cultural value in Seoul. Journal of the Korea Society of Environmental Restoration Technology 17(1): 215-233

Jeong, H.M., Kim, Y.J., Seo, J.W. 2017. Relationships between vessel-lumen-area time series of Quercus spp. at Mt. Songni and corresponding climatic factors. Journal of the Korean Wood Science and 
Technology 45(1): 72-84.

Jung, T.Y., Kim, E.J. 2017. Analyzing the potential of legally protected trees to create community spaces in rural areas - focusing on the case of Gimchon city. Journal of the Korean Institute of Landscape Architecture 45(1): 73-81.

Lee, K.H., Seo, J.W., Han, G.S. 2018. Dating Wooden Artifacts Excavated at Imdang-dong Site, Gyeongsan, Korea and Interpreting the Paleoenvironment according to the Wood Identification. Wood Science and Technology 46(3): 241-252.

Lukaszkiewicz, J., Kosmala, M., Chrapka, M., Borowski, J. 2005. Determining the age of streetside Tilia cordata trees with a DBH-BASED model. Journal of Arboriculture 31(6): 280-284.

Oh, J.A., Seo, J.W., Kim, B.R. 2017. Establishing local master ring-width chronologies and their utilization for estimating the age of big old trees. Journal of the Korean Wood Science and Technology 45(1): 85-95.

Oh, J.A., Seo, J.W., Kim, B.R. 2019. Verifying the possibility of investigating tree ages using resistograph. Journal of the Korean Wood Science and Technology 47(1): 90-100.

Park, S.J., Lee, W.Y., Lee, W.H. 1987. Wood Anatomy and Classification. Hyangmun, Seoul, 60-69.
Park, W.K. 1993. Increasing atmospheric carbon dioxide and growth trends of Korean subalpine conifers. Journal of Korean Forestry Society 82(1): 17-25. Schweingruber, F.H. 1988. Tree Rings - Basic and Applications of Dendrochronology. Kluwer Academic Publishers.

Son, Y.M., Lee, K.H., Kim, R.H., Bae, S.W., Park, B.S. 2007. Measuring the age of trees. National Institute of Forest Science.

Seo, J.W., Choi, E.B., Ju, J.D., Shin, C.S. 2017a. The association of intra-annual cambial activities of Pinus koraiensis and Chamaecyparis pisifera in Mt. Worak with climatic factors. Journal of the Korean Wood Science and Technology 45(1): 43-52.

Seo, J.W., Jeong, H.M., Sano, M., Choi, E.B., Park, J.H., Lee, K.H., Kim, Y.J., Park, H.C. 2017 b. Establishing tree ring $\delta 180$ chronologies for principle tree species (T. cuspidata, P. koraiensis, A. koreana, Q. mongolica) at subalpine zone in Mt. Jiri National Park and their correlations with the corresponding climate. Journal of the Korean Wood Science and Technology 45(5): 661-670.

Wong, C.M., Lertzman, K.P. 2001. Errors in estimating tree age: implications for studies of stand dynamics. Canadian Journal of Forest Research 31(7): 12621271. 